\title{
A República em negativo: 0 sistema conceitual do padre Carapuceiro
}

The Conceptual Sistem of the Priest

Carapuceiro

Silvia Carla Pereira de Brito Fonseca

Professora adjunta do curso de História da Universidade Federal do Estado do Rio de Janeiro (UNIRIO Rio de Janeiro / Brasil) e-mail: silviacarlabrito@bol.com.br

\section{Resumo}

Em 1791 nasceu em Recife o padre e professor de gramática e retórica Miguel do Sacramento Lopes Gama, autor de diversos livros e panfletos políticos, além de cerca de uma dúzia de periódicos publicados entre 1822 e 1852 em Pernambuco e no Rio de Janeiro. 0 presente artigo visa realçar, em primeiro lugar, o emprego pelo redator da semântica histórica como recurso retórico, tendo em vista refutar o ideário republicano. Em segundo lugar procura-se sublinhar a inflexão de suas ideias a partir das propostas de reforma constitucional durante o período regencial.

\section{Abstract}

In 1791 was born in Recife the priest Miguel do Sacramento Lopes Gama, author of many books and political panflets, besides almost twelve journals published between 1822 and 1852 in Pernambuco and Rio de Janeiro. This article deals with, in the first place, the way he used the semantic as a rethorical resourse. Secondly, it intends to underline the change of his ideas in the context of the constitucional reform in the regencial period.

Palavras-chave

semântica, retórica, imprensa

Keywords

semantic, rethoric, press 
1

COSTA, Francisco Augusto Pereira da. Diccionario Biographico de Pernambucanos Celebres. Recife: Typographia Universal, 1882. p.723.

2

BLAKE, Augusto Victorino Alves Sacramento. Diccionario bibliographico brazileiro. Rio de Janeiro: Imprensa Nacional, 1900. p.287.

3

Dialogo entre hum carcunda, hum constitucional e hum federativo do Equador. Pernambuco: Typographia Nacional, 1825. Optou-se por aceitar a autoria de Lopes Gama, não apenas por ele dirigir naquele momento a Tipografia Nacional, mas sobretudo pela afinidade entre as ideias apregoadas então e aquelas enunciadas em seus jornais.

4

Outros jornais teriam sido escritos por Lopes Gama como: O Despertador, 0 Pernambucano (1844) e 0 Sete de Setembro (1845-1846). Cabe acrescentar a edição no Rio de Janeiro da série de artigos " 0 philosopho provinciano na côrte a seu compadre na provincia", além de poemas, sob o pseudônimo "0 Solitario", inseridos na folha Marmota Fluminense em 1852, ano de seu falecimento. SODRÉ, Nelson Werneck. A história da imprensa no Brasil. Rio de Janeiro: Civilização Brasileira, 1966. p.164. Ver ainda a introdução de MELLO, Evaldo Cabral de. O Carapuceiro: crônicas de costumes. São Paulo: Companhia das Letras, 1996. Também é referida a sua participação no Correio Mercantil do Rio de Janeiro por BLAKE, Augusto Victorino Alves Sacramento. Op. Cit., p.287.

5

Entre as principais relacionam-se: TRACY, Conde Destutt de. Memorias sobre quais são os meios de fundar a moral de um povo. Pernambuco: Typographia Fidedigna, 1831; TOROMBERT, Honorio. Introdução aos princípios do Direito Politico. Recife: Typographia de M. F. Faria, 1837; SUZANNE, P. H. Principios gerais de Economia Publica e Industrial em forma de conversações. Pernambuco: Typographia de M. F. Faria, 1837; LYTELTON. A religião cristã demonstrada pela conversão e apostolado de São Paulo. Pernambuco: Typographia de M. F. Faria, 1839; GÉRUZEZ, E. Novo curso de philosophia, redigido segundo o novo programma para o bacharel em Letras. Pernambuco: Typographia de M. F. Faria, 1840; CARMIGNANI. Huma lição academica sobre a pena de morte. Pernambuco: Typographia de M. F. Faria, 1850; PELLICO. Silvio. Dos deveres dos homens. Pernambuco: Typographia de M. F. Faria, 1852.

6

GAMA, Miguel Sacramento Lopes. Selecta classica para leitura e analyse grammatical nas Escolas de Instrução Elementar e para Analyse Oratoria e Poetica nas aulas de Retorica, ordenada pelo $P^{P} M$. S. L. Gama. Recife: Typographia Classica, 1874, $4^{\text {a }}$ edição. Compete citar ainda a publicação do livro A pharpeleida, ou princípio, meio e fim das filhas de Jerusalem com seus visos de poema. Pernambuco: Typographia de M. F. Faria.
Miguel do Sacramento Lopes Gama nasceu em Recife em 1791 e aos quatorze anos iniciou seus estudos, ao ingressar no Mosteiro de São Bento em Olinda. Mudou-se então para a Bahia, onde concluiu o noviciado e lecionou como lente substituto. De volta à terra natal, dedicou-se ao exercício da prédica, obtendo o título honorífico de pregador da Capela Imperial. ${ }^{1}$

Entretanto, sua vida seria consagrada ao magistério, à política $e_{,}$ acima de tudo, à imprensa. Em 1817, quando contava vinte e seis anos, o padre Lopes Gama obteve do então governador Luiz do Rego Barreto nomeação para lecionar a Cadeira de Retórica no Seminário de Olinda, o que foi confirmado mediante Carta Régia em 1821 . $^{2}$

Posteriormente passou à mesma disciplina no Colégio das Artes até 1839, quando é jubilado, alcançando em seguida nomeação para a vicediretoria do Curso Jurídico de Olinda. Além dessas atividades, lecionou, na década de 1840, eloqüência, literatura e retórica no Liceu de Recife, instituição que viria a dirigir a partir de 1850, bem como o Colégio dos Órfãos. Paralelamente, dedicou-se à representação parlamentar, participando das cinco primeiras legislaturas bienais da Assembleia Provincial de Pernambuco a partir de 1835, sendo eleito ao Parlamento nacional em 1852 como representante da província de Alagoas.

Mas inegavelmente foi na imprensa que Lopes Gama mais se destacou, ocupando-se diretamente da redação de inúmeros periódicos entre 1822 e 1852.0 padre beneditino fora responsável pela direção do jornal pernambucano 0 Conciliador Nacional em 1822 e, após curto intervalo de um ano, quando esteve à frente da Tipografia Nacional, deu início à segunda fase da folha entre 1824 e 1825, período em que combateu a Confederação do Equador e provavelmente escreveu o Dialogo entre hum carcunda, hum constitucional e hum federativo do Equador. ${ }^{3}$

Neste período teria dirigido também o Diario do Governo de Pernambuco, publicação impressa na Tipografia Nacional, iniciada a 24 de outubro de 1824 e finalizada no ano seguinte com a extinção da tipografia, sob o governo do general Francisco de Lima e Silva, que sucedera Manoel de Carvalho Paes de Andrade após a derrota do movimento republicano em Pernambuco.

Entre 1829 e 1831 redigiu O Constitucional sob o pseudônimo "0 Sonâmbulo", que seria, aliás, utilizado em correspondências enviadas a outros periódicos pernambucanos, seguido da publicação da folha doutrinária O Popular (1830-1831) e posteriormente 0 Carapuceiro (18321834), jornal satírico que lhe valeria o apelido pelo qual ficou conhecido pela posteridade. A partir de 1835, entretanto, esta folha passa a ser inserida no 0 Diario de Pernambuco. ${ }^{4}$

Convém lembrar, da mesma forma, as diversas traduções ${ }^{5}$, assim como os livros publicados por Lopes Gama, entre os quais o Codigo Criminal da semi-republica de Passamão na Oceania em 1841, o conhecido Lições de eloqüência nacional em 1846, como também um conjunto de textos destinados aos alunos de Retórica, reunidos sob o título Selecta classica para leitura e analyse grammatical nas Escolas de Instrucção Elementar e para Analyse Oratoria e Poetica nas aulas de Retorica, cuja primeira parte, ao contrário das demais, parece ter sido escrita pelo padre beneditino. ${ }^{6}$

Deve-se acrescentar que Lopes Gama obteve a comenda da Ordem de Cristo, como consta na folha de rosto do livro citado acima, além de ter sido membro do Instituto Histórico e Geográfico Brasileiro. 
7

A respeito de Miguel do Sacramento Lopes Gama ver: QUINTAS, Amaro. O Padre Lopes Gama Político. Recife : Imprensa Universitária, 1958; MELLO, Evaldo Cabral de. Introdução. In: Idem (org.). 0 Carapuceiro... Op. Cit. Uma detalhada análise bibliográfica encontra-se em FELDMAN, Ariel. O Império das carapuças: espaço público e periodismo político no tempo das regências (1832-1842). Dissertação de Mestrado. Universidade Federal do Paraná, 2006. Este pesquisador enfatiza os aspectos políticos da obra do padre carapuceiro em detrimento do viés satírico, sublinhado pelos demais autores.

8

Sobre a presença das ideias de Tocqueville nos escritos de Lopes Gama, ver FELDMAN, Ariel. Uma crítica às Instituições representativas no período das regências (1832-1840). Almanack Braziliense, São Paulo, n.4, novembro de 2006. Disponivel em http://www.revistasusp.sibi.usp. $\mathrm{br} /$ scielo.php?script=sci_arttext\&tpid=S180881392006000400004 \&ting=ptetnrm=iso

9

O Carapuceiro, n.30, 23 de agosto de 1834.

10

GUIZOT, François. Teoria do governo representativo. Pernambuco: Typographia de Santos \& Companhia, 1845. p.15.
Não obstante a dedicação ao magistério e à literatura, a imprensa tornaria célebre sua crítica mordaz à venalidade e às demonstrações de patriotismo informadas pelo interesse pessoal. Em todos os temas analisados pelo padre Lopes Gama é possivel entrever uma visão profundamente negativa, tanto da sociedade e dos homens, quanto da atividade política.

Por essa razão, apesar de ser apontado e lembrado pela historiografia ${ }^{7}$ como um mero crítico de costumes, suas ideias e opiniões, além de comportarem um elemento moral que Ihes confere sentido, guardam relação com os preceitos políticos da chamada Escola Histórica da Restauração, que tem em François Guizot seu maior expoente. ${ }^{8}$

0 próprio Gama afirmava que seus "princípios não são certamente bebidos na fonte lodosa e impura do Contrato Social de J. J. Rousseau (...) são princípios extraídos de Aristóteles, de Cícero, de Benjamin Constant, de um Bentham (...), de um Guizot (...) e outros sábios escarmentados por uma triste e funestíssima experiência".

Como se sabe, na Teoria do governo representativo Guizot procura contrapor suas ideias às formas de legitimação do Antigo Regime, assim como aos princípios da soberania popular, tomando por princípio a crítica ao Direito Natural. Por meio da definição do governo representativo como um sistema baseado na capacidade e na razão, tenciona aproximar a democracia aos governos aristocráticos, tendo em vista que em ambos 0 direito à participação política deriva do nascimento. Assim sendo, tanto no poder aristocrático quanto na democracia, a soberania não decorreria da capacidade, mérito ou superioridade intelectual, "mas do fato só do nascimento sem condição alguma".10

De acordo com a teoria de Guizot, o direito à representação política não deveria se relacionar, portanto, à preponderância meramente quantitativa, censurando o que denominava de "despotismo do número". Tal opinião tenderia a redefinir a ideia de governo da maioria, tanto sob o aspecto quantitativo, no sentido da soberania do povo, pois esta contemplaria todos os indivíduos "apenas por existirem, sem mais exigir coisa alguma", quanto do ponto de vista dos direitos pré-estabelecidos. No governo representativo, ao contrário, é examinada a capacidade dos indivíduos - "maioria dentre os mais capazes".11

É preciso considerar que a originalidade do sistema conceitual do padre Lopes Gama vai muito além da aplicação do princípio da "democracia das capacidades", a despeito da estreita afinidade que comportam a apologia e naturalização da desigualdade política, bem como da dependência entre os homens.

Ainda em 1825 no Dialogo entre hum carcunda, hum constitucional e hum federativo do Equador, panfleto no qual o padre Gama constrói uma conversa, ocorrida num botequim, entre os representantes das três correntes de pensamento de então: o "corcunda", símbolo do passado, refratário a todas as reformas e defensor do domínio de Portugal sobre o Brasil; o "federativo" ou republicano, a quem são atribuídos projetos políticos confusos, além de pouco conhecimento sobre os temas em pauta; e o "constitucional", tradução do "justo meio", que, com base em longa e didática explanação, rebate as objeções dos dois primeiros, convertidos em caricaturas políticas. Convém notar que o papel destes no "diálogo" resume-se à proposição de temas que o "constitucional" visa negar ou desenvolver.

Em primeiro lugar, o panfleto ocupa-se das reformas, propaladas pelo "federativo": "enquanto os homens livres não passarem a fio de espada 
Sobre as diferentes identidades das facções politicas do período ver MOREL, Marco. As transformações dos espaços públicos: imprensa, atores políticos e sociabilidades na cidade imperial (1820-1840). São Paulo: Hucitec, 2005; FONSECA, Silvia C. P. de Brito. A idéia de República no Império do Brasil: Rio de Janeiro e Pernambuco (1824-1834). Tese de Doutorado em História. Universidade Federal do Rio de Janeiro, Rio de janeiro, 2004. Ver também BASILE, Marcello 0. N. de Campos. 0 Império em construção: projetos de Brasil e ação política na Corte regencial. Tese de Doutorado em História. Universidade Federal do Rio de Janeiro, Rio de janeiro, 2004

17

Para uma análise minuciosa do "dicionário político" da Nova Luz Brasileira ver BASILE, Marcello 0. N. de Campos. Luzes a quem está nas trevas: a linguagem política radical nos primórdios do Império. Topoi: Revista de História, n.3, Rio de Janeiro, setembro de 2001.

18

Nova Luz Brasileira, n.16, 3 de fevereiro de 1830 todos os Frades e Padres, todos os Fidalgos, todos os condecorados e aristocratas, não temos governo liberal"12. Para o "constitucional", entretanto, as reformas são julgadas necessárias com a condição de serem mantidos os "princípios Monárquicos (...) arraigados nos corações dos Portugueses há tantos séculos"13. Sublinha claramente a disjunção entre o homem e 0 cidadão, ao reivindicar a necessidade dos indivíduos dedicarem-se às suas profissões e não à política: "um sapateiro, por exemplo, de quem a Nação nenhuma outra coisa exige senão que se faça um bom calçado e não pregue calotes, larga o seu ofício dias e dias para questionar em Política, para decidir se o Imperante deve ter ou não ter o veto: se devem (sic) haver uma só ou duas Câmaras"14.

$\mathrm{Na}$ folha $\mathrm{O}$ Constitucional, Lopes Gama retomou o mesmo principio em artigo intitulado Origem da autoridade, das classes e distinção entre os homens:

\begin{abstract}
A Equidade e o interesse da Sociedade, que são inseparáveis, exigem que se distingam, se honrem e se recompensem aqueles que são mais úteis aos seus semelhantes, porque uma igualdade perfeita entre os membros de uma sociedade seria uma verdadeira injustiça (...) eis aqui a fonte natural e legítima da Autoridade e da dependência. Depender de outro é reconhecer a necessidade que temos dele para o nosso próprio bem. A autoridade é o direito de regular nossas ações que reconhecemos e aprovamos quando é depositada em mãos que julgamos mais capazes que as nossas (...)

Tais são os fundamentos naturais da autoridade dos grandes sobre os pequenos, dos ricos sobre os pobres, dos pais sobre os filhos, dos maridos sobre as mulheres, dos amos sobre os servos. ${ }^{15}$
\end{abstract}

Ao final da década de 1820, em meio à crise política do Primeiro Reinado, observa-se o progressivo delineamento das facções políticas que ganhariam maior notoriedade e expressão após a revolução do 7 de abril, ou ao menos entre 1829 e 1834. Cumpre lembrar que, em boa medida, a diferenciação entre liberais exaltados, liberais moderados, e caramurus pode ser estimada com base no respectivo entendimento dos conceitos políticos, como também a partir da postura adotada a respeito das reformas constitucionais, de uma forma geral, e especialmente no que concerne à reforma federalista. ${ }^{16}$

Nesse contexto, inúmeros periódicos elaboraram, com maior ou menor sistemática, dicionários de conceitos políticos, tendo por fim redefinir palavras e conceitos não mais adequados ao que era concebido como um "novo" tempo. Assim sendo, a análise conceitual permite interpretar não apenas os conflitos entre grupos distintos, mas precisamente a chave para apreender suas singularidades.

Importa também ressaltar que era por meio da imprensa doutrinária que os redatores contestavam a interpretação dos conceitos políticos pelos adversários, constituindo-se um verdadeiro diálogo entre os jornais, muitas vezes de províncias distantes. $A$ tal respeito, cabe mencionar o dicionário político da folha fluminense Nova Luz Brasileira, publicado ao longo de 49 dos seus 180 exemplares. De forma elaborada, didática e sistemática, o periódico exaltado imprimiu 108 definições de conceitos, expressões ou frases que constituiam verdadeiras proposições. ${ }^{17}$ Parece significativa a definição do jornal fluminense do conceito de "cidadão": "É o homem (e também a mulher) membro de um corpo Soberano"18. Entretanto, a compreensão deste conceito pelo moderado Lopes Gama justificava a distinção constitucional entre cidadão ativo e cidadão passivo: 
19

O Popular, n.11, 7 de julho de 1830. Pernambuco. Grifado originalmente.

20

Nova Luz Brasileira, n.11, 15 de janeiro de 1830.

21

O Popular, n.22, 14 de agosto de 1830.

22

O Popular, n.15, 21 de julho de 1830.

23

O Carapuceiro, n.30, 23 de agosto de 1834 . Grifado no original.
A palavra Cidadão rigorosamente quer dizer habitador de uma Cidade; depois passou a significar os habitadores de um Reino, uma República, um Estado: mas como nem todos os que habitam em um Estado entram no Pacto Social, deu-se o nome de Cidadãos somente aos súditos de um Governo que compõem a Nação (...).

Ainda que todos os homens sejam iguais em direitos (...) nem todos entram com iguais faculdades na sociedade, nem concorrem com igual porção de meios para 0 benefício geral (...) daqui veio a distinção de Cidadãos ativos e Cidadãos passivos; porque todos os homens não estão nas circunstâncias de gozar das mesmas regalias sociais. ${ }^{19}$

De acordo com o léxico da Nova Luz Brasileira, o conceito de "Povo" seria traduzido como a totalidade dos "habitantes que formam a sociedade e habitam debaixo do mesmo governo", à exceção dos escravos. ${ }^{20}$ Todavia, uma interpretação muito diversa pode resultar da leitura do artigo escrito por Gama, intitulado "O que se deve entender por Povo". Aos olhos do padre beneditino, este seria determinado pela capacidade de reunião:

Não é outra coisa mais do que o agregado de todos os Cidadãos e pessoas que vivem debaixo de certas leis (...) [e não] aquela classe ínfima de qualquer Estado, isto é, aquela gente que não têm meios de vida, que é vadia (...); a esta chama-se propriamente plebe: e quando além de não viver de ofício ou indústria, é grosseira, desaforada e viciosa, chama-se canalha. ${ }^{21}$

A conhecida distinção remetia neste periódico ao exame dos artigos da Constituição, que serviam de mote para a análise conceitual. Destarte, quando afirma que a soberania, "na sua origem, ou essencialmente" reside no Povo, toma essa palavra "no verdadeiro sentido, que é a associação ou comunidade já de governantes e governados: antes desta condição não há Povo, há o que se chama associação anárquica (...). A Soberania, pois, reside originalmente em a Nação que é composta de Magistrados ou executores das leis e de pessoas que lhes obedeçam"22.

Mas a condenação mais explícita à soberania do povo seria desferida quatro anos depois, na folha 0 Carapuceiro, por meio do artigo 0 Absolutista e o Demagogo, publicado pouco depois da aprovação do Ato Adicional, em agosto de 1834. Como fizera em 1825 no Dialogo, Lopes Gama assinala que "a virtude em todas as coisas está na mediania", o que o leva a refutar tanto "o absolutista", "idólatra do poder do Príncipe", quanto "o demagogo do poder do Povo". Aquele, "não achando sobre a terra argumentos que sustentem o seu desvario, vai inquietar o Céu; recorre aos Livros Santos"; este, "derivando a soberania da simples existência, coloca o poder indistintamente na massa do Povo, quer que todo e qualquer indivíduo goze dos direitos políticos só pelo simples fato de ser homem, de maneira que em seu extravagante sistema são frações da soberania, assim os sábios como os ignorantes, tanto o trabalhador como o vadio, o rico e o mendigo (...). Depois imagina um paradoxo denominado vontade geral e dela deriva o justo e o injusto; e chama lei, não o que é conforme aos princípios eternos da natureza do homem, porém sim a expressão dessa intitulada vontade geral"23.

A oposição à soberania popular teria como corolário a apologia da monarquia, valendo-se da correspondência entre o rei e a figura paterna, cuja função seria dirimir as dissensões internas, evitando o "fratricídio" decorrente da guerra civil. "Pretenderam reduzir o Rei a um simples cidadão, substituindo à forma Monárquica a mais escandalosa democracia (...). Cuidaram em fazer tornar para lá [Portugal] o Rei (...) ainda nos ficava o 
26

O Constitucional, n.30, 12 de outubro de 1829.

27

O Popular, n.1, 2 de junho de 1830.

28

Idem, n.7, 23 de julho de 1830. Grifos no original.
Príncipe como penhor da nossa felicidade, intentaram arrancar-nos também o Príncipe (...). Como filhos justamente temerosos da orfandade em que ficávamos, corremos a Ele, pedimos-lhes que nos não desamparasse; ouviu nossas súplicas; ficou entre nós; salvou-nos"24.

Assim, o governo monárquico constitucional representativo que "só pode convir a um Império vastíssimo", é compreendido como aquele que "reúne o que há de melhor em todas as formas de Governo". No entanto, embora sua reflexão aparentemente expresse uma linguagem constitucionalista, a amplitude do poder conferido ao "Ente todo moral", abrangeria, segundo sua visão, a promulgação das leis, a administração da Justiça e o controle de toda a força pública. "Ele é colocado em uma eminência tão elevada que nenhum interesse particular pode ter acesso". Por conseguinte, além da força moral que se eleva acima de todos os indivíduos e os iguala enquanto súditos, do trono "deve emanar o bem público com a perseverança da imutabilidade"25.

É preciso dizer que subjacente ao elogio da monarquia como parte da tradição herdada de Portugal, persiste, e talvez seja essa a chave para o seu pensamento, a perspectiva de guerra social, assim como a negação do país e da população, "mosqueada e cheia de vícios desde a sua infância"26. Contudo, todos os governos seriam ruins "porque todos são filhos da necessidade de conter as nossas paixões criminosas (...). 0 Governo é um remédio à nossa natureza enferma"27.

Destarte, 0 artigo $4^{\circ}$ da Constituição, que refere-se à dinastia imperante, seria tomado pelo padre Gama como matéria para refletir sobre as formas de governo. "A palavra Dinastia é de origem grega e queria dizer possuidor, senhor e passou a significar a Família que os Povos escolheram para dela saírem os seus chefes ou Monarcas. De todos os Governos estabelecidos entre os homens, uma Monarquia hereditária é a que parece, a primeira vista, mais fora de razão e justiça" ${ }^{28}$. Porém, adverte que "onde os Monarcas são eletivos, há uma contínua fermentação de partidos; e é rara a vez em que a escolha não recaia no pior":

\footnotetext{
A experiência tem mostrado que o melhor meio de conseguir essa maior felicidade é haver uma Familia privilegiada de onde saiam os Chefes ou Monarcas que sejam os Executores e Guardas das Leis (...). Mas não basta que o Nosso Imperador tenha o Poder Executivo somente, porque um homem revestido da mera faculdade de fazer executar os Decretos da Assembleia é um serventuário da mesma Assembleia. Esta é composta de homens e pode ser dominada por um partido que nela se forme de homens ambiciosos ou menos interessados no bem público: é preciso que haja quem sirva de defensor do povo, no caso de que o Corpo Legislativo queira fazer-se despótico. ${ }^{29}$
}

Ibidem.
Por essa razão, a excelência de uma forma de governo, conforme 0 argumento pragmático do padre Gama, não se prende ao consenso entre os indivíduos, mas à sua finalidade, ou seja, à segurança. Por conseguinte, a noção de pacto social se vincula menos a uma Constituição, cuja composição tenha origem na representação política, e mais à eficácia do projeto constitucional, enviado para ratificação nas províncias.

Não admira que prescreva a existência de uma autoridade acima da Nação, que controle o Poder Legislativo, uma vez que este "não é independente do voto do Monarca, ao que se chama sanção. Esta palavra vem do Latim - Sanctum facere - e quer dizer aprovação, confirmação, \&t c: logo pela nossa Constituição nenhuma Lei da Assembleia pode ter vigor sem a aprovação do Monarca"30. 
32

Idem, n.33, 22 de setembro de 1830.

33

Dialogo entre hum carcunda ..., 0p. Cit.., p.18.

34

0 Constitucional, n.11, 6 de agosto de 1830 .

35

Dialogo entre hum carcunda ..., Op. Cit., p.20-21.
Porém, ao louvar o bicameralismo, atribui ao Senado não a representação de uma nobreza "que se funda no nascimento", vista como odiosa, mas "a parte mais notável da Nação, isto é: os mais ricos, mais prudentes, mais instruídos \& c c; por isso é que a Constituição no Cap $3^{\circ}$ exige que 0 Senador tenha de 40 anos para cima (...). A palavra Senado vem do Latim Senatus, que quer dizer a reunião de anciãos; porque nessa Língua um homem de maior chamava-se Senex, dai veio o nome de Senado"31. Por outro lado, ao afiançar a vitaliciedade do Senado, concebe a instituição como um corpo político intermediário que evitaria a eliminação do sistema representativo. "Podendo ser esta [a Câmara dos Deputados] dissolvida (...) poderia acontecer que estando o Senado nas mesmas circunstâncias, o Governo assumisse a si todos os Poderes; e como dispõe das Armas, tentasse dar cabo do Sistema Representativo. (...) Para precaver este gravíssimo inconveniente, determinou a nossa Constituição que o Senado seja vitalício." ${ }^{32}$

Com efeito, a noção de liberdade subjacente aos princípios enunciados seria moldada relativamente "aos usos, aos costumes, à educação e ao estado da civilização em que se acham os diferentes Povos"33, não comportando a igualdade entre os cidadãos, vista como "incompativel com a nossa natureza, que nos desiguala pelas faculdades, ou sejam de corpo ou do espírito", mas sim com base na obediência às leis, independente de sua origem, "que remedeiam a desigualdade natural dos homens. Em uma palavra, ser livre é obedecer à lei".34

Não por acaso, a república e a federação seriam os temas mais presentes nas folhas redigidas pelo padre beneditino. Contudo, em que pese 0 reiterado argumento da inadequação desta forma de governo ao pais em virtude da corrupção da população, é possível entrever uma certa inflexão em seu pensamento ao longo das décadas de 1820 e 1830.

Assim sendo, o Dialogo, escrito em 1825, parece refletir a necessidade de objurgar o movimento republicano do ano anterior em Pernambuco. Naquele contexto, Lopes Gama sublinhava a suposta inversão social promovida. "O Brasil tem imensa escravatura, é composto de muitas castas e a forma republicana causaria um transtorno geral de hábitos e costumes (...); era preciso acabar com o maior número, criar homens absolutamente novos, para então estabelecer o Governo que queriam ou diziam querer esses regeneradores da Pátria".35

De qualquer modo, a heterogeneidade da população, a extensão territorial, "a imensa escravatura", bem como o passado, eram vistos como embaraços à instituição da república, argumentos que perduraram ao longo dos anos. Convém notar que a mudança de enfoque parece estar articulada a um deslocamento em sua percepção moral. Semelhante compreensão transparece das diversas opiniões emitidas a respeito do comércio e do luxo, que transita de corrosivo a útil, assim como a mudança de juízo acerca das reformas federais. Esta última inscrita na própria revisão da postura política dos moderados no âmbito da Assembleia Geral que aprovou a lei de outubro de 1832 , na qual se fundamentou o Ato Adicional de $1834 .{ }^{36}$

Parece cabivel supor que num primeiro momento a ideia de república, de acordo com o pensamento político do padre Lopes Gama, correspondia ao temido desrespeito às hierarquias sociais, à anarquia, assimilada à desordem, à guerra civil e à corrupção; ao passo que, num segundo momento, o conceito comportaria uma dimensão utópica que se desloca no tempo.

Por um lado, tal opinião adquiria sentido a partir da percepção da miséria do tempo presente e amparava-se no louvor de um passado remoto 
0 Popular, n.7, 23 de junho de 1830. Grifado originalmente.

38

O Popular, n.53, 12 de março de 1831.

39

GAMA, Miguel Sacramento Lopes. Lições de eloquencia nacional...0p. Cit., vol.1, p.36.

40

Ibidem, Introdução, p.III.

41

O Carapuceiro, n.3, 28 de abril de 1832. e idílico, quando julgava que o comércio e o luxo não haviam corrompido a virtude. Por outro lado, sugeria a idealização do futuro, quando o princípio distintivo da república, na formulação de Montesquieu, viria "espontaneamente" após uma "revolução moral".

"É preciso que os Povos se desenganem que essa palavra Republica não quer dizer o mesmo que felicidade. Hoje não há Repúblicas verdadeiras; porque os nossos costumes, o comércio, que traz infalivelmente o luxo e as luzes do século não oferecem os mesmos dados das Eras antigas". ${ }^{37}$

Em polêmica com o jornal $O$ Republico, de Borges da Fonseca, que reivindicava reformas federalistas na Constituição, Lopes Gama ponderava que a Confederação sob o regime monárquico seria "irrisório até de conceber-se para o Novo Mundo". Mas, sob a forma republicana "todos quereriam locupletar-se e o nosso País tornar-se-ia um circo de gladiadores (...) mormente quando se considera que o progresso das Artes e ciências, o comércio e luxo que têm invadido quase todos os Povos da terra, há tornado quase quiméricas essas virtudes austeras dos Catões e Brutus, e impraticável entre os Povos modernos a Democracia rigorosa. Sejamos prudentes (...) e não nos queiramos deslumbrar por utopias que talvez nos tornariam ao mais duro cativeiro".38

Na década seguinte, ao redigir seu tratado sobre Eloqüência, lembra que esta, ao exercer sua força sobre o convencimento e a persuasão, "isto é procura convencer o entendimento e afinal mover a vontade" ${ }^{39}$, tem sua fase áurea nas repúblicas antigas:

Porque ali para governar os homens era mister persuadir-lhes a necessidade de justiça e da lei, e também porque naquela forma de governo a Eloqüência abria o caminho às dignidades (...) em tempos e paises onde se pudesse impunemente repreender o vício, honrar a virtude e pregar a verdade sem rebuço. E em verdade se Atenas e Roma, tão fecundas de ilustres Oradores em uma idade, mostraram-se tão estéreis em outra foi porque a Eloqüência correu ali, como em todas as partes, a fortuna da liberdade. ${ }^{40}$

Conforme foi visto anteriormente, este segundo momento na concepção de república, de acordo com o sistema conceitual do padre Gama, fica mais evidente a partir de 1832 com a publicação de 0 Carapuceiro - "periódico sempre moral e só per accidens político" - como denunciava o subtítulo.

No terceiro número do jornal cuidava que para instituir a república no Brasil "é mister predispô-la lentamente, fazer a revolução, não física, mas moral, a fim de que (...) estabeleça-se quase por si mesma, e entremos todos na grande Família Americana". Estabelece, dessa forma, uma correlação entre o tempo e as formas de governo: "Já nos conveio a Monarquia; hoje convêm-nos a Monarquia sim, mas Constitucional e Representativa e Federal; para o diante em seu tempo adequado só nos convirá a República, que é a natural tendência da América".41

A insistência na ausência de virtudes, traduzidas aqui como espírito laborioso e morigeração, vistas como mais importantes do que qualquer forma de governo, se desdobra na acusação da prevalência de um sentimento aristocrático que atravessaria toda a sociedade:

Se reflito sobre a classe pobre vejo-a inimiga do trabalho, vejo a Agricultura quase em abandono (...). Basta que qualquer camponês possua um triste escravo para entregar-se ao ócio (...). A classe abastada ordinariamente vive no luxo e nos regalos (...) assim como aqueles só têm a mira nos empregos lucrativos. (...) 
Além disso a Aristocracia entre nós começa desde o mendigo e vai até o mais poderoso proprietário (...). Muitas vezes vemos uma pobre mulher esfarrapada mendigando (...) mas se lhe dão o tratamento de Dona fulana dos Anzóis exaspera-se e faz ver que é ilustríssima. (...) Os proprietários ou senhores de engenho [ilegivel] dos seus maiores a tiranizarem os infelizes escravos (...) nem entendem de outra Constituição, de outros direitos que não sejam os que julgam inerentes à sua alta posição social, isto é: o direito de pisar o pobre e desvalido, o direito de meter no tronco, de espancar e até matar. ${ }^{42}$

Desfecha então um ataque àqueles que apontam os Estados Unidos como paradigma de liberdade e prosperidade, com base na determinação do passado, das diferentes formas de colonização, endossando recorrentes dualidades: "Não macaqueemos os Estados Anglo-Americanos que tiveram outros princípios, outra educação (...). Começaram logo com a Constituição inglesa; o Brasil, com as bárbaras e góticas instituições de Portugal, com a Ordenação do Livro $5^{\circ}{ }^{\prime \prime 4}$

Se as objeções à implementação da república no Brasil amparavamse em conhecidos argumentos, o mesmo não se pode afirmar de sua "teoria" sobre a revolução. Esta, apesar de ser "moral" e não "física", admitiria elementos deterministas que escapariam à ação dos homens, assimilandose a natureza à Providência ou à sua versão secularizada, a Fortuna. "As revoluções Nacionais são como as físicas; não é o homem que as faz; é a natureza das coisas". Assim, servindo-se dessa associação, sugere que:

Certa quantidade de vapores elevados sobre a atmosfera, certa massa de material elétrico produzem os trovões e depuram o ar, abalam a terra [ilegivel] assim certo grau de ilustração e de cultura, certos hábitos, certas precisões que pouco e pouco vão calando no ânimo dos Povos, trazem por si mesmas as Revoluções que mudam às vezes inteiramente a face dos Impérios. Promover, pois, mudanças prematuras ou é de um passo ambicioso, ou se há boas intenções, falta a devida prudência; e neste caso o remédio, longe de curar, só serve de exacerbar [ilegivel] os males. ${ }^{44}$

Relacionadas direta ou indiretamente à temática republicana, as reformas federais também ocuparam inúmeras páginas dos periódicos escritos por Miguel Lopes Gama. À época da publicação da folha O Popular polemizava com o redator de $O$ Republico, ao afirmar a incompatibilidade entre as reformas apregoadas por Borges da Fonseca e os princípios monárquicos. Naquele momento o padre Gama mostrava-se hostil às mudanças na Constituição, assim como minimizava a amplitude da proposta do jornal editado, então, no Rio de Janeiro.

Pareceu-nos que toda a bulha suscitada a este respeito vem a parar em mera questão de nome, isto é, que o Republico chama confederação o que exatamente falando não é mais do que reforma e adição a certos artigos da nossa Constituição atual. Em verdade todas as mudanças apresentadas pelo Republico cifram-se em dar maior amplitude aos conselhos Provinciais (...). 0 Republico aumenta o número de Conselheiros de Província; dá-Ihes ensanchas nas matérias consultivas (...) mudaIhes os nomes de conselhos para Assembleias. ${ }^{45}$

Todavia, a partir de 1832 o padre Carapuceiro passa a reivindicar a implementação de reformas federais na Constituição, salvaguardando a manutenção do "elemento monárquico". Ponderava então que as províncias deveriam ter recursos próprios e não "ir mendigar providências e recursos no Rio de Janeiro".46

Por certo que tanto o significado quanto a extensão das reformas federais são concebidas de forma particular por Lopes Gama, o que gerou 
algumas controvérsias especialmente com o intrépido redator baiano Cipriano Barata. Assim, se por um lado confere à federação o estatuto de pacto social, por outro invectiva contra a gazeta Sentinella da Liberdade, por esta pleitear não apenas a eleição do presidente de província, mas sobretudo a escolha local dos comandantes das armas, dos empregados do erário, assim como de todos os magistrados. Em resposta a Cipriano, garantia que alterar as atribuições do Poder Moderador, assim como ampliar o princípio eletivo retirando do imperador a prerrogativa "de escolher os seus delegados pelas Províncias e a nomeação do Corpo Judiciário" significaria reduzi-lo "a um espantalho (...). Que Monarquia será esta nunca vista em os Tempos modernos? (...) Para que há de o ilustre Soldado da Liberdade assustar ao Povo (...) indigitando uma Reforma, antes total destruição que ainda as pessoas menos atiladas estão enxergando que é uma República nua e crua, como a dos Anglo Americanos pouco mais ou menos.".7

Com efeito, a objeção à eleição dos presidentes de província inscrevia-se na lógica que norteava o pensamento político do padre Lopes Gama. De acordo com seu ponto de vista, a escolha popular fomentaria disputas locais que beneficiariam as famílias poderosas e influentes que, por sua vez, transformariam as províncias em suas propriedades, fazendo-se "Ditadores, e guerras sanguinolentas serão muitas vezes precisas para [os]desmontar (...). 0 Presidente de nomeação do Imperador faz-se e desfaz-se com duas folhas de papel, sem nenhum incômodo, sem perturbação alguma". ${ }^{48}$

No entanto, a veemente censura à corrupção e à venalidade no exercício da atividade pública inspirariam seus melhores textos, repletos de denúncias de improbidade de juizes de paz, desembargadores e deputados, cujas ações e sobretudo opiniões seriam orientadas pela possibilidade de obtenção de prestígio, cargos e rendimentos ilícitos. Para se ter uma medida de sua capacidade de persuasão, foram destacados três artigos que resumem a percepção do professor de retórica a respeito da sociedade em que vivia, bem como do exercício da política em geral.

No primeiro, recorre mais uma vez ao diálogo, construindo duas exposições antitéticas que progressivamente, ao longo do texto, tendem ao acordo, com base na precedência da ambição e do interesse pessoal dos interlocutores, desvendando-se, por meio da ironia e da sátira, a disjunção entre os princípios teóricos e a prática política.

Assim, no Dialogo entre Cosme e Damião, ambos eleitores, inserido no jornal 0 Carapuceiro de 7 de setembro de 1832, Lopes Gama visava satirizar a instituição dos juízes de paz, sufragados diretamente pelos eleitores da paróquia e detentores de poderes policiais e judiciais até a reforma do Código de Processo Criminal em 1841 que, como sabemos, viria a transferir grande parte de suas atribuições aos delegados de polícia, nomeados pelo Ministério da Justiça. ${ }^{49}$

Neste diálogo um dos eleitores, Cosme, pede ajuda ao amigo para ser eleito juiz de paz, não por idealismo, mas em vista de suas "tristes circunstâncias: sou carregado de família, tenho falta de meios, como sabe; em vão procuro pilhar um emprego que me sustente e à minha obrigação: esses ossos são poucos, e os cães, que a eles se atiram, muitos (...). Eis o que de Vm. pretendo e espero". Em resposta, Damião pondera serem parcos os vencimentos neste cargo: "que $V m$. faça diligência por conseguir um ofício (...) nada me parece mais razoável; mas que solicite o pesado cargo de Juiz de Paz, como modo de vida; é o que eu não esperava ouvir de um 
cidadão que se diz tão Patriota. Os caídos desse emprego são tão diminutos e insignificantes, que por esta parte melhor é ser Meirinho".50

Cosme aponta, entretanto, o rápido enriquecimento dos juízes de paz:

Como está Vm. enganado! 0 cargo de Juiz de Paz na mão de quem o sabe aproveitar é uma mina (...). Quantos que dantes andavam roendo as unhas, como Poetas, passam a la grande, até emprestam dinheiros a juros (já sabe com 2 e meio por cento ao mês, que é como Deus manda) depois que empolgaram a varinha de condão de Juiz de Paz? Imagina Vm. que pechinchas podem cair de uma conciliação bem arranjada? ${ }^{51}$

Damião esclarece que o amigo deseja é um cargo que lhe permita "falando em bom romance (...) furtar à sua vontade". Ao que censura o outro o uso da palavra "furtar", "muito nua e de casca duríssima", além do que não apropriada, posto que quando a quantia é elevada "certa é a impunidade (...). Furtar entende muita gente (e eu vou com as turbas) que só é extorquir o alheio, pondo faca aos peitos, salteando pelas estradas, abrindo casas com gazuas, ou arrombando-as de mão armada". Argumenta ainda Cosme que toda a hierarquia do Judiciário - do ministro ao meirinho - "fazem a vida" e beneficiam-se da possibilidade de se apropriar do alheio. "Chega para repartir com o Ministro, que é o primeiro que janta, com o Escrivão que também chupa sofrivelmente, com o Advogado, que é o mestre das traças para o furto, com o Meirinho que não passa sem a sua gorjeta, com o Procurador, que não há de ser tão andejo de graça, e ainda sobra dinheiro".52

Tece então considerações sobre o "gênero humano" explicitando de forma mais enfática sua noção de guerra social:

\footnotetext{
Quase todos os homens na sociedade vivem furtando uns aos outros: o negociante empurra gato por lebre e tem nas faturas um talismã (...) o Empregado de Alfândegas regala-se porque tendo de ordenado $300 \$ \mathrm{rs}$, por exemplo, mora em uma casa de $200 \$$ rs de aluguel, anda mui limpo e asseado, a sua família não menos, tem mesa lauta e opipara, joga patacões (...) como se fossem castanhas, tudo resultado de suas agências; até o Frade, que professa pobreza, assim como o rato ermitão de La Fontaine, que por mortificar-se e desprender-se dos regalos do mundo, vivia dentro de um queijo Londrino, até o Frade, se tem a ventura de receber dinheiros do patrimônio comum, e ao mesmo tempo despender em qualquer gênero de esmola, enche muito bem o seu bolsico (...) Finalmente meu amigo na administração da justiça, são bem poucos os Magistrados que se contentam com os caídos lícitos. Os Ministros do Governo fazem a grande vindima; aos Juizes de Paz justo é que caiba ao menos o rabisco. ${ }^{53}$
}

Damião assinala, entretanto, que para por fim a estes males "é que se proclamou a Constituição". Ao que protesta Cosme que as teorias não informam a prática política; "todas estas teorias são mui lindas, mas falo de fato e não de direito (...). Eu não vejo por toda a parte senão empolgadores, uns mais ladinos e matreiros, outros mais rombos e sinceros." Usa então a metáfora de um ferimento afligido pelas moscas para referir-se ao país e seus parasitas. "Eu comparo o nosso Brasil àquele doente de chagas, a quem um viandante caridoso quis alivio das dores, enxotando as moscas que lhe cobriam (...). Em vez de me beneficiares, exacerbaste as minhas dores; essas moscas que sacudiste já estavam fartas e pouco me aferroavam: novas moscas famintas substituiram aquelas e os meus tormentos serão maiores: convinha afastar tudo quanto é mosca e não tirar umas para dar entrada a outras." ${ }^{54}$ 
55

Cativeiro neste caso tem uma conotação estritamente política, uma vez que coluna era a denominação conferida em Pernambuco aos caramurus.

56

O Carapuceiro, n.21, 7 de setembro de 1832 .

57

Ibidem.
CARVALHO, Marcus J. M. de. Ai vem o CapitãoMor: as eleições de 1828-30 e a questão do poder local no Brasil imperial. Tempo, Universidade Federal Fluminense, Departamento de História, vol.7, n.13, p.157-187, 2002 .
59

O Carapuceiro, n.39, 9 de fevereiro de 1833.
Reivindica então Damião a necessidade de reformas. Estas devem começar pelos homens: "larguemos todos nós os nossos maus hábitos (...) reformemos enfim os nossos costumes que tudo irá bem". Evoca, por assim dizer, a dignidade do cargo de juiz de paz do qual deveriam afastar, segundo seu entendimento, três categorias de indivíduos: "os malandrinos, os colunas, e patriotas de língua; os primeiros por larápios, os segundos porque não querem senão o cativeiro ${ }^{55}$, e os terceiros porque são hipócritas."

Por outro lado, recobra Cosme o arrazoado anterior conclamando o interlocutor a deixar "essas austeridades para os livros; aproveitemos a monção". Propõe então ao amigo uma troca: "faça Vm. com que eu saia Juiz de Paz que eu lhe prometo arranjar muitos votos para que $\mathrm{Vm}$. seja Deputado. (...). De todos os velhos adágios não há um que mais me dê no gosto do que o bem sabido = Ande eu quente, ria-se a gente". ${ }^{56}$

Neste momento o dialogo muda de tom, uma vez que ambos tem em comum a ambição, desaparecendo a partir daí quaisquer críticas. "Eu não estranho que Vm. deseje ser Juiz de Paz com o sempre louvável fim de servir à Pátria. (...) Quanto a sair eu Deputado, não me considero indigno de tão alto emprego", assegura Damião.

Passa então Cosme dos juizes de paz aos deputados, lembrando que estes antes das eleições prometem inúmeras reformas: "sujeito há que antes de pilhar a nomeação de Deputado (...) promete reformar até o Padre Nosso, por ser muito antigo, mas em chegando à Assembleia, que é onde deveria falar, reclamar, etc, faz-se morto, emudece; e os $6 \$ 400$ rs diários correndo-Ihe para a algibeira."

Pondo fim às considerações de ordem moral e política, indaga Damião acerca dos nomes mais cotados para deputado, ao que responde Cosme que "os inimigos da Federação não são os que trabalham menos para encher a Deputação de gente de sua confiança (...) [mas] não há muito que fiar, porque em chegando à Corte, muitas vezes sopra-Ihes outro vento e mudam de rumo". Conclui, portanto, sugerindo que "quem puder pesque que o tempo não está para menos. Amor de pátria, interesse público, isso são virtudes de poucos".57

A descrença na eletividade dos magistrados seria ainda objeto de artigo do padre Lopes Gama, ao comparar o poder conferido ao juiz de paz às arbitrariedades cometidas pelo antigo capitão-mor. Efetivamente, a justaposição do juizado de paz aos antigos corpos de ordenanças e milícias resultaria em conflitos de jurisdição, revelando um entrecruzamento das atribuições legais das novas e antigas instâncias de controle e repressão. ${ }^{58}$

Confesso que há entre nós Juizes de Paz mui honrados, zelosos e animados das melhores intenções; porém o seu número é incomparavelmente menor do que o dos indignos, não só por ignorância, senão por escandalosa malícia.

Ninguém ignora o que eram, principalmente pelos matos, uns Bachazinhos chamados Capitães Mores, (...). Não eram Militares e comandavam uma horda de estropiados, de miseráveis ceroulas, intitulados Ordenanças que compunham o seu batalhão. A qualquer hora do dia ou da noite mandavam invadir a casa do pobre e desvalido. (...). Todos os bons cidadãos que se horrorizavam desse Sultanismo folgaram de ver a utilíssima criação dos Juizes de Paz, aspirando que esses abusos tão escandalosos decrescessem consideravelmente. (...). Mas infelizmente não tem sucedido assim. Os Juizes de Paz (...) mormente os do mato, vão fazendo o mesmo e por ventura pior. ${ }^{59}$

No segundo texto satírico, o professor de retórica tencionava convencer o leitor da "artificialidade" dos princípios políticos, ao construir uma 
60

Idem, n.49, 20 de abril de 1833

Ibidem.

Ibidem. caricatura da virtude cívica. Para tanto, valeu-se da narrativa de uma sessão dos "Pescadores da Pátria", na qual os participantes relacionavam suas mudanças de opinião e de conduta política às oportunidades de enriquecimento. Assim sendo, o primeiro personagem afirmava ter sido republicano até perceber que tal propensão não havia Ihe logrado nenhum benefício pessoal. Voltou-se então para os moderados, incorporando seu vocabulário específico:

Confesso, Snr. Presidente, que fui um democrata horroroso (...). A República era o meu [ilegivel]; eu a queria estabelecida ainda que fosse na Ilha de Fernando; se lia em algum Escritor público o mais leve elogio ao Imperador, desatinava de indignação; cobria de baldões ao infame Periodista, e nos Botequins, meu tribunal competente, desbravava a minha ira declamando contra ele e enchendo-o dos maiores impropérios (...). Vendo porém que as minhas teorias nada fundiam para os meus intentos, observando que até ali não tinha pescado nem uma piaba, deixei-me arrastar das melífluas palavras de certos Moderados; passei-me para eles e sentime outro homem (...) não tinha na boca senão as palavras canalha, anarquista e outras coisas piores; e em uma botica (onde às vezes a par da Farmacopéia estão os Benjamins Constants, os Benthams, e os Contratos Sociais), quase jogo a murrada com certo bilhostre por proferir em minha presença a heresia política de que o exMinistro de Estado; o Snr Feijó era da marca de Judas. ${ }^{60}$

A nova inclinação política teria surtido o efeito desejado, chegando ao "conhecimento de certos leitões, chamados pais da Pátria, e no mesmo ponto fui inscrito no catálogo dos que deviam ser Deputados". Mas, como não há como confiar nos homens: "Já recebia parabéns, já me aprontava de roupa e mobília, já tinha tomado certo ar de importância (...) e eis que me vejo bigodeado, sem anzol, sem isca e sem peixe. (...) Estou de ânimo a fazer-me Miguelista que é fonte limpa".61

0 segundo personagem, estudante do curso de Direito, precavido, declara: "já agora vou chumbando (...). Sou um furioso coluna da Regência porque dela espero o pescado." Ressalta que tem sido alvo de críticas dos colegas "todos uns anarquistas, revolucionários e farroupilhas" que em breve, "se arrependerão de não quererem ser pescadores".62

0 terceiro personagem admitiu ter sido simpático à "Federação" em 1824, assim como ter apoiado a Sociedade Federal quando surgiu em Pernambuco: "as lojas, os botequins, as esquinas eram os meus Pórticos, os meus Liceus, as minhas Academias (...) fiz-me um Federalista energúmeno (...). em uma loja quase me engalfinho, e jogo os socos e bofetões com um ignorante que teve a ousadia de sustentar no meu queixo que nós não estávamos nas circunstâncias da América Inglesa. Eu lhe fiz ver que estávamos em melhores porque já tínhamos uma fábrica de toalhas e guardanapos, outra de chapéus finos, de Rapé na Bahia, de seda no Rio de Janeiro, (...) e possuiamos um Código Criminal que não lembrou a Platão na sua República, nem o possuem melhor a França, a Inglaterra e os Estados Unidos."

A despeito das promessas, "pregaram-me o logro e fiquei sem ao menos um camarão. Afio, declaro que (...) tornei-me um unitário furioso, defendo o atual Governo faça ele o que fizer; tudo que não pensa como eu vai raso de descomposturas; tudo é anarquista; tudo é farroupilha. Quero ver (...) se assim pesco: se pescar bem, vou por diante fazendo o meu papel de amigo da ordem: do contrário tomarei outro rumo e proclamarei ou a República ou a D. Pedro 10"63

0 terceiro texto destacado - também uma veemente condenação ao luxo e à prodigalidade nos cargos públicos - narra a transformação da 
GAMA, Miguel Sacramento Lopes. Selecta classica para leitura e analyse..., Op. Cit., p.33. Grifos no original.

65

HOLANDA, Sérgio Buarque de. Raízes do Brasil. Rio de Janeiro: José Olympio, 1987. p.50 e ss.

66

0 Carapuceiro, n.32, 6 de setembro de 1834 . Grifo no original. vida, assim como dos hábitos, outrora austeros, que comportariam o cargo de desembargador, para a opulência e ostentação de riqueza.

Antigamente em um lugar destes que é o que cabia? Cabia o doutor com os seus textos e umas poucas de postilas, muito usadas e por isso muito honradas. Cabia mais uma mula (...) se a casa estava muito longe (...). Cabiam os filhos honestamente vestidos, mas a pé, e com a arte debaixo do braço: cabia a mulher com poucas jóias, e as criadas, se passavam da unidade, não chegavam ao plural dos Gregos. Isto é o que cabia naquele lugar antigamente (...).

Andaram os anos, o lugar não cresceu e tem mostrado a experiência que é muito mais sem comparação o que cabe no mesmo lugar. Primeiramente cabem umas casas ou paços que as não tinham tão grandes os condes de outro tempo: cabe uma livraria de Estado tamanha como a do Vaticano, e talvez com os livros tão fechados como ela os tem: cabe um coche com quatro mulas, cabem escudeiros: cabe a mulher em quarto apartado, com donas, com aias, e com todos os outros arremedos de fidalguia: cabem os filhos com cavalos e criados e talvez com o jogo (...): cabem as filhas maiores com dotes e casamentos (...): as segundas nos mosteiros com grossas tenças: cabem tapeçarias, cabem baixelas, cabem comendas, cabem benefícios, cabem meios de renda: e sobretudo cabem umas mãos muito lavadas e uma consciência muito pura e infinitas outras coisas que só na memória e no entendimento não cabem. ${ }^{64}$

As denúncias de corrupção e venalidade desvendam apenas uma faceta da crítica social de Miguel Lopes Gama. 0 divórcio entre a adoção de princípios doutrinários e a prática política, a onipresença de um espírito aristocrático espraiado por toda a sociedade, desdobrando-se na primazia deposta no trabalho mental e no correlato desprezo pelos ofícios mecânicos, são temas recorrentes em quase todos os seus textos, notadamente na folha 0 Carapuceiro.

A denominada "praga do bacharelismo", expressão consagrada na antológica análise de Sérgio Buarque de Holanda ${ }^{65}$, não escapara à argúcia do padre Gama, relacionada, já à época, aos hábitos infundidos pela sociedade escravista. No artigo Satisfação aos meus antagonistas, após arrolar inúmeras mazelas da sociedade, indaga:

São gerais os bons costumes? Respondam sinceramente os mesmos Republiqueiros (...) que já temos a precisa moralidade quando estamos vendo a venalidade em todas as Repartições (...) o espírito orgulhoso e despótico em quase todos os Delegados do Poder (...) Terá a palavra República alguma virtude sobrenatural que trazmude (sic) pedras em filhos de Abraão? (...) Todos o que querem é ter bons réditos com pouco ou nenhum trabalho (...). Ninguém quer saber de fábricas de ofícios mecânicos e muito menos da Agricultura, manancial da mais sólida riqueza, entregando a braços escravos e forçados o que mais deve honrar a homens livres.0s mesmos ofícios fabris são olhados com desprezo: o ferreiro, por exemplo, que no meu entender, (...) merece muito mais estima do que o Desembargador ladrão, logo que tem um filho não cuida em o fazer aprender o seu ou qualquer outro ofício mecânico, pelo contrário, trabalha por mandá-lo para o Curso Jurídico na esperança de o ver em poucos tempos Juiz de Direito; porque entre nós a fofice principia no mendigo e acaba no Senado do Império. ${ }^{66}$

A imprensa tampouco escaparia às carapuças talhadas pelo padre Gama. Os alvitristas ou periodiqueiros, como os denominava, são impiedosamente ridicularizados em vista de ignorância da língua pátria, associada às freqüentes citações em francês, assim como o apreço pelos lugares comuns. Ironiza ainda sua propensão às polêmicas calorosas em contraste com as promessas de comedimento e moderação dos primeiros números 
67

o Carapuceiro, n.24, 30 de setembro de 1832.

68

O Carapuceiro, n.37, 30 de janeiro de 1833.

69

Ibidem.

70

lbidem. dos jornais. A longa citação, mais uma vez, se justifica pela notável aptidão do professor de retórica, não somente para persuadir os leitores, mas pela representação que faz da sociedade de seu tempo.

Em entrando na cabeça de qualquer a mania de Redator, ele se considera desde logo por uma fonte inesgotável de luzes (...)

Ordinariamente estréia-se (...) por um cabeçalho enfadonho debruado de lugares comuns, quase sempre extraídos (...) de algum livrinho Francês; porque hoje quem alinhava a sua tradução desse idioma, por mais bordalenga e engorovinhada que seja, é filósofo, economista chapado, jurisconsulto, estupendo político (...) e não carece de estudar mais nada. 0 zelo do bem público o come (...) o amor da Pátria the dá pulos no coração; a Liberdade é o seu ídolo (...) e toca a borrar papel.

0 primeiro № soe aparecer com pés de lã. Ali o ilustre Escritor, que é sempre Político, Literário e Enciclopédico, sempre desinteressado e Imparcial (...) promete ser mais modesto que uma Vestal, mais sincero do que Sócrates (...). Mas daqui a poucos passos, vai o diabo que não dorme, nem guarda cabras, mete-se na cabeça de outro Redator, que fez iguais ou maiores promessas no nascedouro, para censurar qualquer coisa do seu ilustrado colega (...). Acende-se desta centelha uma guerra civil na república Periodiqueira (...).

Os grandes luzeiros da Pátria convertem-se em tições para tisnar a quantos não partilham de seus sentimentos; os Catões censurinos trocam-se em Catelinas furiosos; os Confúcios morigerados degeneram em Protágoras virulentos e os homens de grandes planos mais parecem ravinhosas regateiras do que cidadãos que se dão a si mesmos tanta importância. ${ }^{67}$

Outro tema que merece a reflexão de Lopes Gama é o vínculo entre a Igreja Católica e a monarquia. Em artigo intitulado Altar e Trono, que tem como preocupação central especular a origem desta associação, padre Gama afirmava nada encontrar nas Escrituras que indicassem uma predileção da "Divindade" pela realeza; "pelo contrário, na Lei antiga vejo o mesmo Povo de Deus regido por um Governo misto de Aristocracia e Democracia no tempo dos Juizes" ${ }^{68}$. Tampouco no Novo Testamento encontra inclinações do "Divino Mestre" à monarquia: "nunca foi, nem poderia ser de sua intenção, impor a Nações inteiras, a tantos milhões de entes racionais a obrigação de sofrer aos seus Déspotas". Recobra, por essa razão, o direito de resistência ao tirano, ao qual São Paulo chama "obséquio racionável"69.

Portanto, questiona-se, quais motivos levariam à obediência a outro homem "chamado Rei, ordinariamente muito mal educado e quase sempre os piores de todos os homens?" Seriam inconciliáveis, pergunta-se, o Altar e a Democracia, ou o Altar e a Aristocracia? Seriam estas formas de governo incompativeis com a religião católica? "Certamente que não. Veneza e Florença, na meia idade, foram regidas muitos anos pelas suas Repúblicas Aristocráticas; e nesse mesmo tempo tão religiosas foram que deram muitos Santos à lgreja"70.

Conforme seus argumentos, a associação entre a monarquia e a Igreja Católica advinha dos "padres impostores" que apadrinham e acolhem à sombra do altar "as patifarias, as prepotências, as crueldades do Trono", tendo em vista que o querem "absoluto no temporal porque trabalham para que o Altar também o seja no espiritual; querem que os Reis governem o corpo a seu bel prazer a fim do Altar poder tirar todos os lucros e vantagens do domínio da consciência (...). São Padres e Frades de nenhuma caridade e nenhum espírito Religioso e comumente de crassíssima ignorância (...) querem o trono absoluto para roubarem à sombra dele", conclui o padre beneditino.

Além da sátira e da ironia, o expediente de descrever um "sonho", cujo conteúdo vaticinasse profecias aterrorizantes era relativamente 
0 padre Gama chama a atenção em seu Lições de eloqüência nacional para a utilização de figuras como a prosopopéia definida por ele como a "introdução de falas do verdadeiro Deus ou das Divindades do Paganismo, ou ainda de pessoas já falecidas e, para assim dizer, evocadas do túmulo que se chama Idolopeia." 0p. Cit.., p.189.

O Carapuceiro, n.65, 16 de agosto de 1833. comum na imprensa da época e dele também se valera Lopes Gama. ${ }^{71}$ Publicado originalmente na folha 0 Carapuceiro e transcrito duas semanas depois no periódico 0 Federalista, o artigo narrava um suposto sonho do redator no qual uma "figura veneranda que bem parecia já não pertencer à mortalidade" declarava ser: "aquele Pernambucano que, sempre avesso aos tiranos, em público patíbulo expiei o crime de amar muito a minha Pátria"72.

Tratava-se de frei Caneca a advertir a respeito da ameaça de restauração do "pérfido Duque de Bragança". Assim, o "gênio tutor de Pernambuco" viria acender no ânimo dos concidadãos aquele amor patriótico e "patentear-Ihes o horroroso quadro que lhes está preparado se unidos não souberem repelir a sanguinolenta catástrofe da Restauração; certos futuros não são escondidos aos olhos dos imortais. E isto dizendo, uma força invisível como que me arrebatou a outra morada".

Impossível não observar a mudança de linguagem, assim como seu juízo acerca do eminente mártir da Confederação do Equador. Dando seguimento ao "sonho", descreve então todas as calamidades que adviriam a Pernambuco com a restauração do "monstro Bragantino".

\footnotetext{
Vi as formosas ruas da nossa Mauricéia ermas e desertas, ouvi o lúgubre som dos campanários que anunciavam aos poucos vivos a morte desastrosa de seus concidadãos, vi (...) cadafalsos alterosos levantados em todos os bairros. Quem é aquele Militar brioso que com as mãos atadas, com grosseiro laço ao pescoço caminha com tardo pé ao medonho lugar do seu suplício? Quem é aquele Sacerdote pacífico que, degradado das vestes Pontificiais e das sagradas ordens (...) vai por força levado ao matadouro? São todos Brasileiros; são cidadãos livres que por inexperientes e desunidos não puderam resistir (...)

Pernambucanos, refleti bem neste bosquejo e permita-o Deus (...) nunca seja realizado o horrivel sonho do Escritor do Carapuceiro. ${ }^{73}$
}

Parece razoável afirmar que nas ideias de Lopes Gama é possivel entrever um conflito entre uma perspectiva política ainda referida ao Antigo Regime, informada, além disso, pela onipresente noção de guerra social, e uma linguagem constitucionalista, não vinculada à sua conformação, mas à eficácia política.

Assim, se num primeiro momento a república aterrorizava por assimilar-se à anarquia, à insubordinação social, à democracia e à guerra civil, num segundo momento é definida como utópica, cujo alcance dependeria de uma revolução moral, desencadeada por elementos físicos, que infundissem virtudes, aqui compreendidas como austeridade e probidade no exercício das funções públicas, morigeração nos hábitos e apreço pelos ofícios mecânicos. Nas suas palavras a república dependeria da criação de "homens novos".

Além disso, a transformação observada em suas ideias também pode ser aferida pela própria memória da Confederação do Equador, bem como por meio da percepção da autoridade política. A esse respeito, se em 1825 convocava o "Defensor Perpétuo", aclamado pelo "Clero, Nobreza e Povo", expressando uma linguagem típica do Antigo Regime, para "salvar-nos da orfandade" e da guerra civil; na década seguinte, redefine implicitamente sua avaliação do movimento republicano em Pernambuco, ao evocar a imagem do "mártir patriota", "gênio tutor de Pernambuco", para advertir e combater a temida ameaça de restauração do "monstro Bragantino". 
Não obstante, alguns elementos essenciais permanecem. Em primeiro lugar, a descrença na condição humana, ou a ideia de uma "natureza enferma", apenas remediada por meio de um governo desvinculado da sociedade; em segundo lugar, a noção de utopia, empregada para se referir à república, transitando do passado remoto ao imprevisível futuro.

É mais que provável que eu já não exista para esse tempo (...). Consola-me de sobejo o pressentimento de que então, acalmadas as paixões nas áreas cinzas do sepulcro, os meus Patrícios me farão Justiça e dirão - 0 Escritor Fulano trabalhou quanto cabia na (...) sua esfera por aplainar-nos o caminho da República, que agora convém-nos; e então não. ${ }^{74}$

o Carapuceiro, n.32, 6 de setembro de 1834 